$\xi=-1$

\title{
Maintenance Management Model: an Identification of Key Elements for Value-Based Maintenance Management by Local Authority
}

\author{
Sylvia Gala Mong ${ }^{1 *}$, Sarajul Fikri Mohamed ${ }^{2}$, Mohd. Saidin Misnan ${ }^{3}$ \\ ${ }^{1,2,3}$ Department of Quantity Surveying, Faculty of Built Environment, \\ Universiti Teknologi Malaysia, 81310 Skudai Johor, Malaysia. \\ *Corresponding author E-mail:sylviagalamong@gmail.com
}

\begin{abstract}
Maintenance management is a crucial element which governs the economic value of the organization itself. The maintenance management portrays the practice of leading and turning the organization through the deployment and handling of available resources such as financial, human, material, knowledgeable and technology. Consequently, the maintenance management needs to be emphasized by any means of planning, directing, implementing and controlling and several improving methods to achieve economic aspects of the organization. This paper covers part of the study to examine the current practices of the local authorities in Malaysia in maintenance management of public facilities. A systematic literature review has been carried out to identify the existing models and frameworks related to maintenance strategies formulation, selection and its implementation. The literature support for all the key elements needed to achieve valuebased maintenance management. Few models of maintenance management were examined to acquire the essential elements before proposing the maintenance management model for local authorities. By analyzing the models, it characterizes the innovations introduced by every author and compares the elements based on maintenance standard requirement for maintenance processes. Also, the discussion is made on the key elements to be included and improved to support organization needs and its application.
\end{abstract}

Keywords: Maintenance Management; Value-based Maintenance; Maintenance Management Model

\section{Introduction}

The cost of maintenance is rising due to fast changing of maintenance strategies and resources, forcing the organisation to consider the proactive maintenance management to encounter the maintenance issues, not just for a cost-saving measure. Maintenance management is a crucial element which governs the economic value of the organisation itself. The maintenance management portrays the practice of leading and turning the organisation through the deployment and handling of available resources such as financial, human, material, knowledgeable and technology. All activities of management are determining the objectives, and the priorities set out by the organisation, includes the strategies, responsibilities and implementation. Therefore, the maintenance management needs to be emphasised by any means of planning, directing, implementing and controlling and several improving methods to achieve economic aspects of the organisation.

Many maintenance management models and framework has established in recent years with different features and concept. However, the maintenance management still on the focus due to poor performance value in cost, asset utilisation, resource allocation, health and safety, etc. (1). Many organisations today, operate competitively in the business environment and often conflicting on the requirement. However, for the non-profit organisation such as local authority, they are regulated concerning financial support and resources which constraint them to efficiently work in managing their asset and services (2-5). The cost of maintenance is ris- ing due to fast changing of maintenance strategies and resources, forcing the organisation to consider the proactive maintenance management to encounter the maintenance issues, not just for a cost-saving measure. Maintenance management is a crucial element which governs the economic value of the organisation itself. The maintenance management portrays the practice of leading and turning the organisation through the deployment and handling of available resources such as financial, human, material, knowledgeable and technology. All activities of management are determining the objectives, and the priorities set out by the organisation, includes the strategies, responsibilities and implementation. Therefore, the maintenance management needs to be emphasised by any means of planning, directing, implementing and controlling and several improving methods to achieve economic aspects of the organisation.

The primary objective of the study is to determine the key elements that are vital towards value-based maintenance management Therefore, this study will pinpoint the elements from various types of maintenance management models before proposing a new structure for maintenance management based on a systematic literature review of a significant number of related articles that were published in a selected journal related to maintenance management. The elements will be used as the primary variables to generate the proposed maintenance management model for the local authority. A critical review of the literature will be carried out for identifying the said variables. The proposed maintenance management model aims to align the maintenance objectives with the overall local authority's organizational goals. The proposed model stipulates the operational perspective and considering the inevita- 
ble challenges that might affect the effectiveness of the management of the local authority. The viable maintenance management will help the local authority's organization to serve better the community continuously

\section{The Significance of Maintenance Manage- ment}

Maintenance management consists of the activity-based work planning and budgeting that includes planning, scheduling, assigning, implementing and evaluating the strategies. The maintenance management creates the cost for the works and specifies the performance standards that need to be achieved by the organization (6). The maintenance management comprises of the four stages: Planning, Organizing, Directing and Controlling (7). The administration provides a systematic approach that establishes what types of works that need to be done, when it should be done, what resources is necessary for every kind of jobs, and what are the related cost required. Therefore, the organization able to determine the commitments and accountability of their roles in the providing best quality of the facilities and services (8).

The evolution of the maintenance management from recent years has shown the significance of the maintenance activities that have taken place against the pressure of erecting up a new building (9). Moreover, the development of maintenance management has increased parallel with the new application of technologies, and it allows the efficient organization and management of maintenance data. However, there are still the circumstances that the maintenance activity does not practice an integrated approach in dealing with the building performance; thus the potential of the building cannot be seen entirely (10)

\section{Value-Based Maintenance Management}

Poor maintenance management contributes to financial drain to the organization as it can limit the real performance of the organization. Other than that, the organization is facing significant harms and very risky to its buildings and assets, people and the continuation of the organization performance $(11,12)$. Therefore, effective maintenance management can contribute to an organization in achieving its strategic goals concerning efficient management, reputation and can satisfy the stakeholders. The maintenance organization must be able to understand the value of the maintenance management that can bring the best practice to the organization, as they can align their strategies and operations towards demonstrating and delivering the best maintenance management.

Maintenance has no fundamental value as it is conducted to support the organizations' main objectives and strategic function of the building (13). The goals of maintaining the value of the maintenance of an organization need to be emphasized so that the organization can perform the maintenance management can support the core business and support the needs of the stakeholder (14-20):

- The effective maintenance management contributes to the sustainable and cost-effective maintenance to the organizations;

- The good practices encourage the productivity of the organization and facilities operation;

- Continual quality improvements in keeping the pace of the organizations to remain competitive and relevant;

- Enhancing the workplace and facilities safety, security and comfort to the stakeholders and users can lead to the reliability building services.

As stated by Stenström et al., (2013), there are four maintenance value drivers represent the core of the maintenance function in the organization which are: resource allocation; cost control; asset utilization and health and safety (Figure 1). Therefore, each of these value-drivers must be considered by balancing the importance of maintenance management in the organization and maximize the stakeholders' value.

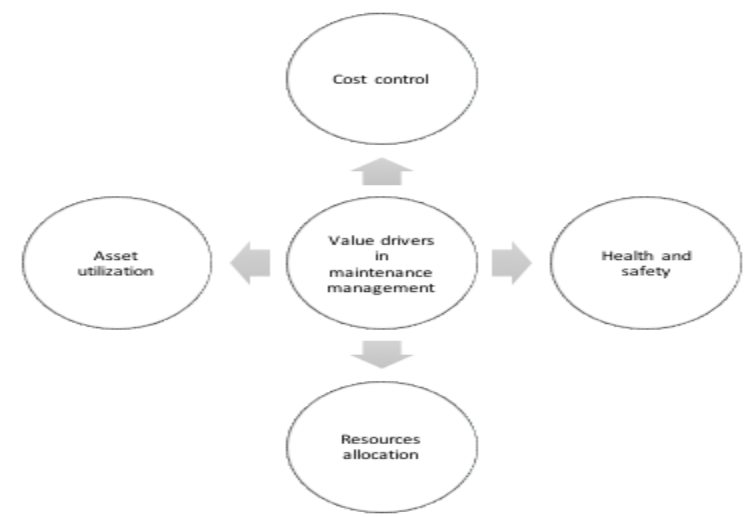

Figure 1: The value drivers in maintenance management (21).

Maintenance management not only just warranting the functionality of the equipment or services of the asset but also denote the essential parts to achieve the goals and objective of the organization by using optimum resources and maximize the productivity (22). Previously, the industry player only focusing on the issues of resources such as financial, workforce and technology. Recent years, the innovation of the maintenance management evolved and the concern has shifted to the consideration of the long-term goal, strategic management and sustainability (23). Researchers and practitioners started to show the interest to achieve the best value in maintenance management to ensure the organization can achieve their business goals by focusing the value drivers for strategic maintenance management.

\section{Maintenance Management Models}

According to BS EN 13306:2010, maintenance management combines the administrative, managerial and technical activities that establish the maintenance objectives, strategies and responsibilities, implementation of policy to achieve organization's goal. As the maintenance and the management become the strategic importance to the organizations, many examinations and studies related to the maintenance have triggered the industry players and researchers to explore the benefits and contributions of effective maintenance management (24). Across the years, there were numerous models describes the maintenance management processes within a various kind industry. From the review made from the selected sources, the authors identified few models within the literature varies from books and articles. Table 1 describes the models and framework for maintenance management.

Table 1: Existing models and frameworks for maintenance management

\begin{tabular}{|c|l|}
\hline Author & \multicolumn{1}{c|}{ Models and Frameworks } \\
\hline$(25)$ & $\begin{array}{l}\text { Breakdown maintenance; total productive maintenance } \\
\text { (TPM); condition-based maintenance (CBM) and reliabil- } \\
\text { ity-centred maintenance (RCM); run-to-destruction; pre- } \\
\text { planned maintenance; and campaign maintenance. }\end{array}$ \\
\hline$(26)$ & $\begin{array}{l}\text { Basic terotechnology model; advanced terotechnology } \\
\text { model; total quality maintenance (TQMain); EUT model; } \\
\text { RCM; TPM and Kelly's philosophy. }\end{array}$ \\
\hline$(27)$ & $\begin{array}{l}\text { Scheduled maintenance; CBM; condition monitoring (CM); } \\
\text { RCM; TPM; TQMain, predictive condition monitoring; } \\
\text { operating maintenance training and administration; run-to- } \\
\text { failure; corrective maintenance; planned maintenance; } \\
\text { preventive maintenance (PM); equipment asset mainte- } \\
\text { nance; preactive maintenance, productivity reliability; } \\
\text { proactive maintenance and profit centre maintenance }\end{array}$ \\
\hline (28) & $\begin{array}{l}\text { PM; CBM; TPM; RCM; computerised maintenance man- } \\
\text { agement system (CMMS); predictive maintenance; out- } \\
\text { sourcing; effectiveness-centred maintenance; strategic }\end{array}$ \\
\hline
\end{tabular}




\begin{tabular}{|l|l|}
\hline & maintenance management and risk-based maintenance. \\
\hline$(29,30)$ & European Foundation for Quality Management (EFQM); \\
& TPM; Enhanced telecommunication operation maps \\
& $\begin{array}{l}\text { (eTOM); Capability maturity model integration (CMMI); } \\
\text { Control objective for information and related technology } \\
\text { (COBIT) }\end{array}$ \\
\hline
\end{tabular}

As for maintenance management models, two different types are distinguished through its purpose and approach. Each of the models has the limits in the in enumerating the elements and information that needed for the strategic maintenance model. Table 2 shows the explanation of each type of model.

Table 2: Models classification for maintenance management $(31,32)$

\begin{tabular}{|c|c|}
\hline Declarative model & Process-oriented model \\
\hline $\begin{array}{l}\text { - Describe the management } \\
\text { maintenance components and do } \\
\text { not refer to the connection be- } \\
\text { tween those elements in the pre- } \\
\text { cise form. }\end{array}$ & $\begin{array}{l}\text { - Typically offer a clear infor- } \\
\text { mation flow among their compo- } \\
\text { nents, and in some of these mod- } \\
\text { els, inputs and outputs of the } \\
\text { maintenance management model } \\
\text { are identified }\end{array}$ \\
\hline $\begin{array}{l}\text { - A clear information flow among } \\
\text { the components is not distin- } \\
\text { guished, and therefore, some } \\
\text { functional, interrelation and syn- } \\
\text { chronization aspects cannot be } \\
\text { precisely appreciated }\end{array}$ & $\begin{array}{l}\text { - These models seem to be of } \\
\text { easier application in organiza- } \\
\text { tions than declarative models, } \\
\text { they require proper definition } \\
\text { concerning the coordination } \\
\text { among their elements to be effec- } \\
\text { tive, and this description is some- } \\
\text { times missing }\end{array}$ \\
\hline $\begin{array}{l}\text { - Some of these models are very } \\
\text { complete, including a great vari- } \\
\text { ety of aspects and tools related to } \\
\text { maintenance. }\end{array}$ & $\begin{array}{l}\text { - A tidier system through some } \\
\text { complexity degree in the imple- } \\
\text { mentation process compare to } \\
\text { declarative models }\end{array}$ \\
\hline
\end{tabular}

Also, the maintenance management model has evolved through researches by practitioners and researchers. It is likely to recognize the trends in the development of maintenance management models as the various industry started to get the sense of the importance of maintenance for the business goals. The evolution of the technology and system which focuses on the process and quality and the availability of standard and procedure specified to support the decision making for maintenance management. The maintenance management model either as declarative or processoriented helps the organization to fulfil the requirement for better performance and contribute the best value in maintenance management $(31,32)$.

\section{Methodology}

This paper purposely to explore various models related to the maintenance and its management. Textbooks and selected journals in hard copy and online were reviewed thoroughly which consists of established publishers such as Emerald, Elsevier, Wiley, Blackwell Publishing, Springer. The scope of research on the selected articles focusing on the journal of maintenance, quality engineering, productions, facilities management, facilities, operations, manufacturing, maintenance, and reliability. In reviewing the selected articles journals, the author used some keywords, terms to describe the maintenance concepts. The study covers various terms which may be different in meanings and understanding from each author and references: maintenance philosophies; maintenance strategy; maintenance approach; maintenance techniques; maintenance processes; maintenance management. To achieve consistency and reliability, the authors attempt to use two terms to identify the related maintenance management which is "model" and "framework". These two terms can provide significant numbers of methods, techniques and strategies.

For comparison purpose to obtain the key elements that needed for developing the strategic and value-based maintenance management model, the authors have made the selection of five different models and framework. The criteria for selection were: $i$. The articles and book sections have the keywords of maintenance management "model" and "framework".

ii. The models and framework focus on the processes of maintenance management.

iii. The articles are published in indexed journals and established publisher.

$i v$. The models and framework presented in a graphical or diagram.

v. Every five models deal with different scope and purpose The authors are using the list of elements that provided in the British Standard BS EN 13306:2010 and ISO standard 9001:2015.

The elements that are chosen for comparison of selected models and frameworks are as follow:

$i$. The element related to organization management and responsibility (policy, organization objectives, responsibility and commitment top to bottom)

ii. The element related to quality management (strategy, approaches, techniques, processes)

iii. The element related to resources management (financial, people, materials and equipment)

$i v$. The element related to performance measurement, analysis and improvement (information analysis, reports, benchmarking, auditing, continuous improvement)

These elements practice by a various organization in managing their asset and buildings. The elements will be used as the primary variables to generate the propose maintenance management model for the local authority. A critical review of the literature will be carried out for identifying the said variables in the discussion to support the justification. A focus on selected studies related to the maintenance management with different features and characteristics of the building will be combined with systematic methods of study-selection and results exploration. Selected articles from various indexed journal will be the source of information.

\section{Finding and Discussion}

During the process of reviewing the maintenance management models, it seems that countless evolution of the maintenance processes and management. However, some of the researchers and study are still in need of justification as no specific terms are being standardized. Some practitioners and researches are using different terms and analogy in their explanations which may refer to the same characteristics. The main objective of maintenance management is optimizing the life cycle of the asset; by maximizing the availability and reliability functional of the asset to achieve the organization objective. Therefore, the maintenance not only focusing on the technology issues as it comprises various management for operation, resources, financial and business strategies (33). Based on Table 3, the authors aim to identify the parameters which are the elements that need to be integrated into the proposed maintenance management model. The parameters are obtained based on the requirement stipulated in ISO 9001:2015 (2015) and established textbooks on maintenance which are (9,35-37):

i. Maintenance policy, objectives and strategy formulation

Traditionally, the maintenance objective is derived from the organization objectives and translated into the strategy maintenance. The organization may have long-term maintenance plans which will be integrated with the business plans. The essential component is the company must understand that they need to link the objective and policy of business plan and maintenance strongly. Strategic selection of maintenance needs to be done by considering the organization structure, maintenance strategies, resources available and supporting system (35). However, it is challenging to align the maintenance objective, strategy and performance measurement with the overall business strategy (37),. These discrepancies and unsatisfactorily can be resolved through the usage of Balanced Scorecard (BSC) $(28,38,39)$. The $\mathrm{BSC}$ can be one of the main tools for the organization to 
employ the decision making for strategy formulation based on the business objectives. Therefore, based on the models compared, (30) have indicated the practice of BSC in their maintenance strategy formulation together with the objectives. The maintenance strategy that can support the overall business strategy can satisfy the expectations of the internal and external stakeholders as stipulated in ISO 900I:2015. What is clear is that the assessment needs to be suitable and equivalent to the scope and standard while considering the interest of the stakeholders (40-43).

ii. Maintenance organization management

The term organising denotes the process of arranging the available resources such as people, materials and technology. The maintenance organisation needs to be embraced together to achieve the organisation's goals and objective. Therefore, it is important to have the interaction between the inputs and outputs in the systems so that the various parts of the organisation can communicate with the maintenance manager. $(35,44,45)$. In the ISO 9001:2015 ( 2015), also outlined the importance of the organisation to ensure the quality of the system and commitment are assured. Each model as describes in Table 3 has described the function of the organisation management in various ways such as maintenance level with different roles and responsibilities after determining the maintenance objective and goals. The leadership from the top management is very crucial to demonstrate the commitment as concerning the management system $(46,47)$. The roles of the top management need to have skills and knowledge to allocate the sufficient resources and making the decision how the resources can be maximized. The need to provide the organisational chart to indicate the responsibilities and facilitate cooperation between each level of management; to avoid the overlapping and interdepartmental boundaries scope of works (45).

iii. Maintenance planning and scheduling

Maintenance planning aims to ensure that the necessary works considered executed within the maximum economy and satisfy the effectiveness and efficiency criteria (36). The crucial feature of planned maintenance is any anticipated failures detected can be remedied by any means of strategic approaches to prevention and rectification. Therefore, proper maintenance task can be done after having the data collection on the problem phase to develop the maintenance plan. This task includes gathering the information on the technical documents, improve safety and work environment, increase the effectiveness of maintenance operation and considering the views and inputs of an organization. Few researchers must study the production forecasting, decision for maintenance and the reliability of the equipment and customers' needs $(16,48)$. The selection of strategy and techniques to satisfy the requirement of maintenance depending on the resources available and support system (information system, training and performance management) $(19,20,36,49,50)$. However, the uncertainty may exist due to some circumstances that cannot be predicted such as the characteristics of the asset (lifetimes, building features, design), uncertainty of the specific cost due to budget constraint which limit the potential maintenance task to carried out and the value to achieve; either in asset utilization, cost control, health and safety and resources availability $(48,51,52)$. As stated in Table 3 , most of the model has the element of planning which is the critical success for effectiveness and provide the best value to the organization and depending on how the team execute the tasks.

iv. Operation management

The execution of the maintenance activities being conducted at the operational level. This stage is very critical as mostly the issue usually arises due to insufficient and inadequate efforts to maximize the available resources. During the execution stage, the focus will be on the technical requirements of maintenance. The operational level denominates this task; therefore, they must be well-trained and motivated (33). The human resources must be knowledgeable to handle the pressure from the top management to fully utilized the specified allocation and strategy. The scope of work in the operational stage started with the building inspection and assessment to maintenance implementation $(35,53)$. Most of the models described in Table 3 have indicated the maintenance execution which is the focus of the maintenance strategy implementation

v. Resources allocation

The resources needed for maintenance consists of the human resources, spare parts, tools and information. The quality of human resources will depend on the environment of the company; the training system, the availability of skill and expert in the particular scope of maintenance work (7). Knowledge of the maintenance can be obtained through training; hence, the tasks can be done effectively and efficiently. The organization can adopt outsourcing the job in case of shortage of skills. However, by outsourcing and provide training to the workforce, the organization cannot merely justify the cost reduction for maintenance task as they have spent to the improvement of performance(22).

Spare parts must be able to achieve the optimal balance between the cost of ordering and holding. Moreover, to manage the spare part, the setting should be classified and recorded in the inventories $(54,55)$. However, Table 3 shows only a few describe the resource allocation being considered in the maintenance management models; whereas the resources must be the vital element for maintenance management to be considered. Consequently, the organization must be able to decide the strategic allocation of resources to achieve the lowest value of cost for desired response and work quality.

vi. Financial control

Budget is the main mechanism of financial control which is the predetermined state of the maintenance policy of the organization. The budget is a means of associating the financial resources with the planned maintenance expenditure $(9,36)$. The maintenance cost created through the technical and economic feasibilities of maintenance plans. The value of financial control can be assessed through the performance report each of the years. Therefore, a budget is an essential tool for financial control to ensure the organization prepare and understand the commitment towards the strategic maintenance objectives (35). The primary concern regarding the maintenance cost is budget constraints and cost overrun (56-58). Since each of the maintenance strategies has different technical specifications and resources, the cost for each of the maintenance plans needs to be well-planned to avoid maintenance cost issue. Based on Table 3, some of the models did not justify and indicated the financial control in their maintenance management; it is a must to show the budget or financial management as to achieve the best value in cost especially to the non-profit organization such as the local authority.

vii. Information management

Information is the most important component that required to make any justification and decision. It can define as the knowledge, details and fact for any occasions. Therefore, information management is crucial for maintenance since the early phase of decision making for maintenance. Inadequate information can lead to confusing or wrong decision making for maintenance and can contribute to a high expenditure (56-58). Information is consisting of the condition assessment and performance of an asset, information on the organization policy, data on resources available, etc. The proper decision only can be made merely if the data information is sufficient and correct. Though it is complicated to determine the sufficiency of the report, the possibilities of prediction 
are established through the cause-and-effect relationship. The performance of an asset will be justified through the indicators that developed in the earlier phase of maintenance management (33). Table 3 shows mostly the information management related to the computerized maintenance management system (CMMS) that helps and guide the organization to implement the maintenance strategy. Due to the advanced technology, the various medium of information storage and the channel has been developed and being used by the organization to manage their asset $(59,60)$.

viii. Performance assessment and control

The performance measurement for maintenance management is the essential principle of governance. It identifies the performance of the items that has been maintained. The comparisons are made to examine the progress and gaps between the current and preferred performance. The performance indicator can be used to justify the next action to be taken $(22,38)$. At the early stage of maintenance management, the organization has established the maintenance objective to achieve and therefore set the performance indicators to evaluate the performance of the maintenance management (61-63). Parida \& Kumar (2009) also in the study has concluded that the maintenance performance measure various inputs and it has become the complex issues to justify (61). Therefore, different indicators are needed for each component of the maintenance processes to benchmark the best practices to achieve the best value of maintenance management $(34,64,65)$. Table 3 also indicates each of the models provides the view of performance measurement as one of the important elements that need to be incorporated.

Figure 2 shows the maintenance processes in line with the maintenance management within the organization. Those elements specified in Table 3 were included to show the interconnectivity with the organization business goal. The proposed maintenance management model aims to relate the scope of function of the maintenance department with the organization to ensure the business's goals and objective can be achieved. It is very important for the maintenance management team to understands the flow of maintenance process to offer the better output of the organization especially the local authorities as they serve the public for convenience and comfortability.

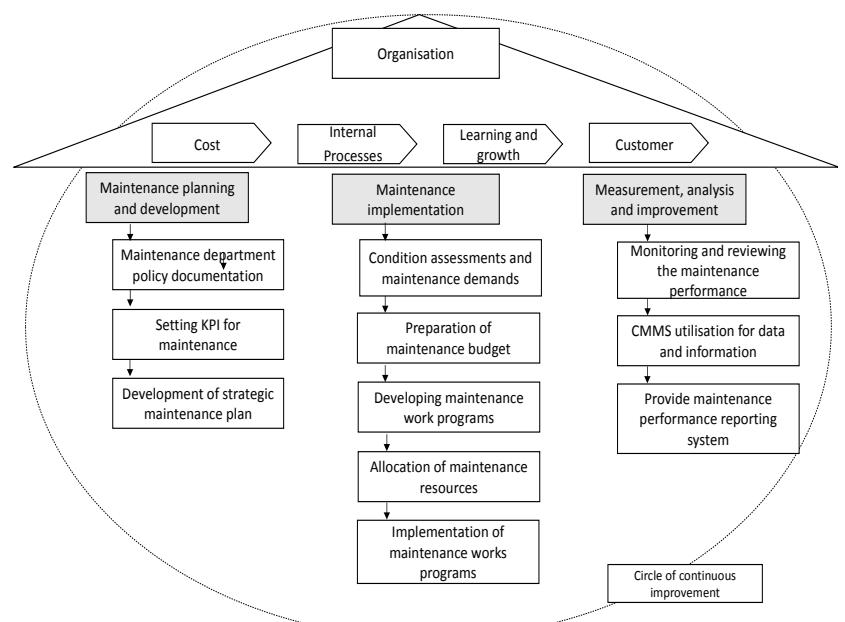

Figure 2: The proposed of maintenance management model for local authority

\section{Conclusion}

This paper reviews research work conducted on the existing maintenance management models and frameworks with different types of organization, building features, management characteristics and policy. The current maintenance management elements mostly propose subjective criteria and strategies leading to possible ways to encounter the maintenance issues and challenges to achieve the sustainable maintenance cost. The viable maintenance cost will help the local authority's organization to serve better the community continuously. By having the value-based maintenance management model, many benefits can be achieved as crucial for the organization especially the non-profit organization such as the local authority. The advantages are as follow $(32,44,66,67)$ :

$i$. The participation and support of management team;

ii. Coherent organization structure;

iii. Improvement in productivity and profits;

iv. Development of skills and knowledge;

$v$. Health and safety establishment and security;

$v i$. Overall reduction of emergencies and shutdown of equipment and services; and

vii. Effectiveness and efficiency in managing the asset.

The proposed maintenance management model aims to align the maintenance objectives with the overall local authority's organizational objectives. The proposed model stipulates the operational perspective and considering the inevitable challenges that might affect the effectiveness of the management of the local authority. To achieve the economic value of the public facilities, the proposed management model will be derived based on the desirable characteristics; practical, modern, strategic valuable support to overcome maintenance issues by considering the value in cost, asset utilization, health and safety and resources allocation.

\section{References}

[1] Marais KB, Saleh JH. Beyond its cost, the value of maintenance: An analytical framework for capturing its net present value. Reliab Eng Syst Saf. 2009;94(2):644-57.

[2] 2Atan R, Abdul Raman S, Sawiran MS, Mohamed N, Mail R. Financial performance of Malaysian local authorities: A trend analysis. In: 2010 International Conference on Science and Social Research (CSSR 2010) [Internet]. 2010. p. 271-6. Available from: http://ieeexplore.ieee.org/lpdocs/epic03/wrapper.htm?arnumber=57 73782

[3] Brackertz N. Relating physical and service performance in local government community facilities. Facilities [Internet]. 2006;24(7/8):280-91. Available from: http://www.scopus.com/inward/record.url?eid=2-s2.033646878084\&partnerID=tZOtx3y1

[4] Yilmaz S, Beris Y, Serrano-Berthet R. Local Government Discretion and Accountability: A Diagnostic Framework for Local Governance. 2008;(113):37.

[5] Hopland AO, Kvamsdal SF. Optimal maintenance scheduling for local public purpose buildings. Prop Manag [Internet]. 2016;34(2):120-35. Available from: http://www.emeraldinsight.com/doi/10.1108/PM-01-2015-0002

[6] Wireman T. Developing Performance Indicators for Managing Maintenance [Internet]. 2005. 250 p. Available from: https://books.google.com/books?hl=en\&lr=\&id=qSTOnEwyraUC\& pgis $=1$

[7] Kelly A. Managing maintenance resources. 2006. 312 p.

[8] Mastor SH, Ibrahim N. Quality management (QM) practices in facilities management (FM) organisation: A case study in Malaysia. ISBEIA 2012 - IEEE Symp Business, Eng Ind Appl. 2012;635-40.

[9] Chanter B, Swallow P. Building Maintenance [Internet]. Vol. 6, Property Management. 2007. 1-9; 19-29; 108-111 p. Available from: http://www.emeraldinsight.com/doi/abs/10.1108/eb006688

[10] Lavy S. Performance-Based Facility Management - An Integrated Approach. Int J Facil Manag. 2010;1(1):1-14.

[11] Lee HHY, Scott D. Overview of maintenance strategy, acceptable maintenance standard and resources from a building maintenance operation perspective. J Build Apprais. 2008;4(4):269-78.

[12] Nik-Mat NEM, Kamaruzzaman SN, Pitt M. Assessing the maintenance aspect of Facilities Management through a Performance Measurement System: A Malaysian case study. In: Procedia Engineering. 2011. p. 329-38.

[13] Tam ASB, Price JWH. A maintenance prioritisation approach to maximise return on investment subject to time and budget constraints. J Qual Maint Eng [Internet]. 2008;14(3):272-89. Available 
http://www.emeraldinsight.com/10.1108/13552510810899472

[14] Kuhn AW. Best practices in real property management in state governments. J Facil Manag. 2003;2(2):108-20.

[15] Talib Y, Rajagopalan P, Yang RJ. Evaluation of building performance for strategic facilities management in healthcare: A case study of a public hospital in Australia. Facilities [Internet]. 2013;31(13):681-701. Available from: http://www.emeraldinsight.com/10.1108/f-06-2012-0042

[16] Al-Turki U. A framework for strategic planning in maintenance. J Qual Maint Eng [Internet]. 2011;17(2):150-62. Available from http://www.emeraldinsight.com/doi/10.1108/13552511111134583

[17] Lateef OA. Building maintenance management in Malaysia. J Build Apprais. 2009;4(3):207-14.

[18] Au-Yong CP, Ali AS, Chua SJL. Interval of Routine Maintenance and Maintenance Performance: A Literature Review. MATEC Web Conf. 2016;

[19] Puksite I, Geipele I. Different Approaches to Building Management and Maintenance Meaning Explanation. Procedia Eng [Internet]. 2017;172:905-12. Available http://dx.doi.org/10.1016/j.proeng.2017.02.099

[20] Pelantova V, Cecak P. NEW ASPECTS OF MAINTENANCE MANAGEMENT AND THE MATERIAL OF SPARE PARTS MM Sci J. 2018;(March):2283-9.

[21] Stenström C, Parida A, Kumar U, Galar D. Performance indicators and terminology for value driven maintenance. J Qual Maint Eng [Internet]. 2013;19(3):222-32. Available from: http://www.emeraldinsight.com/doi/10.1108/JQME-05-2013-0024

[22] Velmurugan RS, Dhingra T. Maintenance strategy selection and it impact in maintenance function: A conceptual framework. Int $\mathbf{J}$ Oper Prod Manag. 2015;35(12):1622-61.

[23] Ganisen S, Jawahar Nesan L, Mohammad IS, Mohammed AH Kanniyapan G. Facility management variables that influence sustainability of building facilities. J Teknol. 2015;75(10):27-38.

[24] Fraser K, Hvolby H-H, Tseng T-L (Bill). Maintenance management models: a study of the published literature to identify empirical evidence [Internet]. Vol. 32, International Journal of Quality \& Reliability Management. 2015. 635-664 p. Available from: http://www.emeraldinsight.com/doi/10.1108/IJQRM-11-2013-0185

[25] Stoneham D. Maintenance Management and Technology Handbook 1st ed. Elsevier Advanced Technology, Oxford; 1998

[26] Sherwin D. A review of overall models for maintenance management. Vol. 6, Journal of Quality in Maintenance Engineering. 2000. 138-164 p.

[27] Mostafa SI. Implementation of proactive maintenance in the Egyptian Glass Company. Journal of Quality in Maintenance Engineering 2004 p. 107-22.

[28] Amik Garg and S.G.Deshmukh. Maintenance management: literature review and directions. J Qual Maint Eng. 2006;12(3):20538.

[29] Crespo Marquez A, Gupta JND. Contemporary maintenance management: Process, framework and supporting pillars. Omega. 2006;34(3):313-26.

[30] Crespo A, Viveros P, Barbera L. Advanced model for maintenance management in a continuous improvement cycle : integration into the business strategy. 2012;

[31] Campos ML, Márquez AC. Review, Classification and Comparative Analysis of Maintenance Management Models. IFAC Proc Vol [Internet]. 2008;41(3):239-44. Available from: http://www.sciencedirect.com/science/article/pii/S14746670153557 25

[32] Sillivant D. Review, Classification and Comparative Analysis of Maintenance Management Models. In: Proceedings - Annual Reliability and Maintainability Symposium. 2015.

[33] Sullivan GP, Pugh R, Melendez AP, Hunt WD. Operations \& Maintenance Best Practices. U S Dep Energy, Fed energy Manag Progr [Internet]. 2010;(August):321. Available from: http://energy.gov/sites/prod/files/2013/10/f3/omguide_complete.pdf

[34] ISO 9001:2015. ISO 9001:2015 QUALITY MANAGEMENT SYSTEMS - REQUIREMENTS (Guidance Document) [Internet]. 2015 p. 15. Available from: https://www.dnvgl.be/publications/thenew-iso-9001-2015-6317

[35] Duffuaa SO, Ben-Daya M. Handbook of Maintenance Managemen and Engineering [Internet]. Handbook of Maintenance Management and Engineering. 2009. 223-235 p. Available from: http://www.scopus.com/inward/record.url?eid=2-s2.084892338874\&partnerID=tZOtx3y1

[36] Paul Wordsworth. Lee's Building Maintenance Management . 4th Edition. 2001;1-9.
[37] Márquez AC. The Maintenance Management Framework: Models and Methods for Complex Systems Maintenance [Internet]. The Maintenance Management Framework. 2007. 333 p. Available from:

http://books.google.com/books?hl=en\&amp;lr=\&amp;id=a4Rsl001 SmUC\&amp;oi=fnd\&amp;pg=PA3\&amp; $\mathrm{dq}=\mathrm{The}+$ maintenance $+\mathrm{m}$ anagement+framework+:+models+and+methods+for+complex+sys tems+maintenance\&amp;ots=rfqVNv5VZv\&amp;sig=W5Lpannm mmcLFg-t8Ka26T6dVzU

[38] Tsang AHC, Jardine AKS, Kolodny H. Measuring maintenance performance: a holistic approach. Int J Oper Prod Manag [Internet] 1999;19(7):691-715. Available from: http://www.emeraldinsight.com/doi/abs/10.1108/014435799102716 74

[39] Salonen A, Deleryd M. Cost of poor maintenance. J Qual Maint Eng [Internet]. 2011;17(1):63-73. Available from: http://www.emeraldinsight.com/doi/abs/10.1108/135525111111162

[40] Rosni NA. Collections of Views from Stakeholders on Public Facilities in Kajang: An Islamic Guide. J Archit Plan Constr Manag [Internet]. 2014;4(1). Available from: http://journals.iium.edu.my/kaedjournal/index.php/KAEDJournals/a rticle/view/89\%5Cnhttp://journals.iium.edu.my/kaedjournal/index.p hp/KAEDJournals/article/download/89/99

[41] Duan C, Deng C, Gharaei A, Wu J, Wang B. Selective maintenance scheduling under stochastic maintenance quality with multiple maintenance actions. Int J Prod Res [Internet]. 2018;7543:1-19. Available from: https://doi.org/10.1080/00207543.2018.1436789

[42] Vilarinho ${ }^{\mathrm{a}} \mathrm{S}$, Lopes ${ }^{\mathrm{a}}$ I, Oliveira ${ }^{\mathrm{a}}$ JA. Preventive maintenance decisions through maintenance optimization models : a case study. 2017;11(June):1170-7.

[43] Söderholm P, Holmgren M, Klefsjö B. A process view of maintenance and its stakeholders. J Qual Maint Eng. 2007;13(1):19-32.

[44] Daragh Naughton M, Tiernan P. Individualising maintenance management: a proposed framework and case study. J Qual Maint Eng [Internet]. 2012;18(3):267-81. Available from: http://www.emeraldinsight.com/doi/10.1108/13552511211265802

[45] Lateef Olanrewaju A, Idrus A, Faris Khamidi M. Investigating building maintenance practices in Malaysia: a case study. Struct Surv [Internet]. 2011;29(5):397-410. Available from: http://www.emeraldinsight.com/doi/abs/10.1108/026308011111824 20

[46] Elmualim A, Shockley D, Valle R, Ludlow G, Shah S. Barriers and commitment of facilities management profession to the sustainability agenda. Build Environ [Internet]. 2010;45(1):58-64. Available from: http://dx.doi.org/10.1016/j.buildenv.2009.05.002

[47] Islamiah S, Sani A, Mohammed AH, Misnan MS, Awang M Determinant Factors in Development of Maintenance Culture in Managing Public Asset and Facilities. Procedia - Soc Behav Sci [Internet]. 2012;65(ICIBSoS):827-32. Available from: http://dx.doi.org/10.1016/j.sbspro.2012.11.206

[48] Lind H, Muyingo $\mathrm{H}$. Building maintenance strategies: planning under uncertainty. Prop Manag. 2012;30(1):14-28.

[49] Crespo Márquez A, Moreu de León P, Gómez Fernández JF, Parra Márquez C, López Campos $\mathrm{M}$. The maintenance management framework. J Qual Maint Eng [Internet]. 2009;15(2):167-78. Available

from: http://www.emeraldinsight.com/doi/full/10.1108/135525109109611 10

[50] Palmer RD. Maintenance Planning and Scheduling Handbook [Internet]. The McGraw-Hill Companies. 2004. 861 p. Available from:

http://onlinelibrary.wiley.com/doi/10.1002/cbdv.200490137/abstrac

[51] Gao L, Guo R, Zhang Z. An augmented Lagrangian decomposition approach for infrastructure maintenance and rehabilitation decisions under budget uncertainty. Struct Infrastruct Eng [Internet]. 2011;9(5):448-57. Available from: http://dx.doi.org/10.1080/15732479.2011.557388

[52] Idrus A, Khamidi MF, Lateef OA. Value - Based Maintenance Management Model for University Buildings in Malaysia-A Critical Review. J Sustain Dev. 2009;2(Figure 1):127-33.

[53] Booty F. Facilities Management Handbook. Facilities Management. 2006.

[54] Kelly A. Maintenance Systems and Documentation. ButterworthHeinemann. Elsevier Ltd; 2006.

[55] Arts JJ. Spare Parts Planning and Control for Maintenance 
Operations. 2013. 1-229 p.

[56] Ali AS. Cost decision making in building maintenance practice in Malaysia. J Facil Manag. 2009;7(4):298-306.

[57] Ali AS, Chua SJL. Issues and Challenges in Implementation of Planned Maintenance. Prof J R Inst Surv Malaysia. 2011;46(4):337.

[58] Seidenberg FAMFU. Problem-solving approaches in maintenance cost management: a literature review. J Qual Maint Eng. 2016;22(4):334-52.

[59] McArthur JJ. A Building Information Management (BIM) Framework and Supporting Case Study for Existing Building Operations, Maintenance and Sustainability. Procedia Eng. 2015;118:1104-11.

[60] Motawa I, Almarshad A. A knowledge-based BIM system for building maintenance. Autom Constr. 2013;29.

[61] Parida A, Kumar U. Maintenance productivity and performance measurement. Handb Maint Manag [Internet]. 2009; Available from: http://link.springer.com/chapter/10.1007/978-1-84882-472$0 \_2$

[62] Enshassi AA, Shorafa F El. Key performance indicators for the maintenance of public hospitals buildings in the Gaza Strip. Facilities [Internet]. 2015;33(3/4):206-28. Available from: http://emeraldinsight.com/doi/pdfplus/10.1108/F-07-2013-0053

[63] Róka-Madarász L. Performance measurement for maintenance management of real estate. Acta Polytech Hungarica [Internet]. 2011;8(1):161-72. Available from: http://www.scopus.com/inward/record.url?eid=2-s2.079955368085\&partnerID=40\&md5=3f862df2c56dc3d5b57828c12 $96 \mathrm{fa} 45 \mathrm{c}$

[64] Edmond W.M. Lam APCC and DWMC, Lam EWM, Chan APC, Chan DWM. Benchmarking success of building maintenance projects. Facilities [Internet]. 2010;28(5/6):290-305. Available from: http://www.emeraldinsight.com/10.1108/02632771011031529

[65] Liu Y De. Implementing and evaluating performance measurement initiative in public leisure facilities: An action research project. Syst Pract Action Res. 2009;22(1):15-30.

[66] Márquez, Adolfo Crespo JFGF. Maintenance Management in Network Utilities. Springer. 2006;352.

[67] Marais KB. Value maximizing maintenance policies under general repair. Reliab Eng Syst Saf. 2013;119:76-87.

[68] Söderholm P, Holmgren M, Klefsjö B. A process view of maintenance and its stakeholders. J Qual Maint Eng [Internet]. 2007;13(1):19-32. Available from: http://www.emeraldinsight.com/doi/10.1108/13552510710735096

[69] Barberá L, Crespo A, Viveros P, Stegmaier R. Advanced model for maintenance management in a continuous improvement cycle: Integration into the business strategy. Int J Syst Assur Eng Manag. 2012;3(1):47-63.

[70] Harun MT, Salamudin N, Hushin HF. Appraisal of the sport facilities maintenance management practices of Malaysian Stadium Corporations. Asian Soc Sci. 2013;9(12 SPL ISSUE):93-8.

[71] Chemweno P, Pintelon L, Horenbeek A Van. Asset maintenance maturity model : structured guide to maintenance process maturity. Int J Strateg Eng Asset Manag. 2015;2(2):119-35. 
Table 3: The identification of elements of maintenance management models and frameworks

\begin{tabular}{|c|c|c|c|c|c|}
\hline Parameters & $\begin{array}{l}\text { Söderholm et al., } \\
\text { (2007) }\end{array}$ & Idrus et al., (2009) & Barberá et al., (2012) & Harun et al., (2013) & $\begin{array}{c}\text { Chemweno et al., } \\
\text { (2015) }\end{array}$ \\
\hline Model/framework & $\begin{array}{l}\text { Maintenance process } \\
\text { model }\end{array}$ & $\begin{array}{l}\text { Value maintenance } \\
\text { management model } \\
\text { for Malaysian Univer- } \\
\text { sity Campuses }\end{array}$ & House of maintenance & $\begin{array}{l}\text { Sports facilities } \\
\text { maintenance manage- } \\
\text { ment model }\end{array}$ & $\begin{array}{l}\text { Asset maintenance } \\
\text { maturity model }\end{array}$ \\
\hline Model objective & $\begin{array}{l}\text { A holistic view of } \\
\text { maintenance to align } \\
\text { the maintenance pro- } \\
\text { cess with other indus- } \\
\text { try internal processes } \\
\text { and fulfil external } \\
\text { stakeholder }\end{array}$ & $\begin{array}{l}\text { An alternative mainte- } \\
\text { nance management } \\
\text { model for university } \\
\text { buildings in Malaysia }\end{array}$ & $\begin{array}{l}\text { The model aims to } \\
\text { align the local mainte- } \\
\text { nance objectives with } \\
\text { the overall business } \\
\text { objective. }\end{array}$ & $\begin{array}{l}\text { The model unites the } \\
\text { elements for effective } \\
\text { maintenance manage- } \\
\text { ment, the concept of } \\
\text { planning, organizing, } \\
\text { implementing, leading } \\
\text { and control of sports } \\
\text { facility. }\end{array}$ & $\begin{array}{l}\text { A structured guide for } \\
\text { implementing new } \\
\text { maintenance pro- } \\
\text { grams, evaluating } \\
\text { existing programs and } \\
\text { directing continuous } \\
\text { activities. }\end{array}$ \\
\hline $\begin{array}{l}\text { Maintenance policy, } \\
\text { objectives and } \\
\text { strategy formulation }\end{array}$ & $\begin{array}{l}\text { Maintenance objective } \\
\text { established by the } \\
\text { stakeholders' require- } \\
\text { ment }\end{array}$ & $\begin{array}{l}\text { The maintenance } \\
\text { objective to align with } \\
\text { the university mission } \\
\text { and vision. }\end{array}$ & $\begin{array}{l}\text { Explain in stage } 1 \\
\text { about the current } \\
\text { situation and obtain } \\
\text { the accurate perfor- } \\
\text { mance of the asset. } \\
\text { The realistic mainte- } \\
\text { nance objective to } \\
\text { align with the business } \\
\text { objective. The asset to } \\
\text { be ranked according to } \\
\text { the critical impact. }\end{array}$ & $\begin{array}{l}\text { Describe under plan- } \\
\text { ning stage concerning } \\
\text { organizational objec- } \\
\text { tive, maintenance } \\
\text { objectives, strategic } \\
\text { and operational plan- } \\
\text { ning }\end{array}$ & $\begin{array}{l}\text { Practices of mainte- } \\
\text { nance decision making } \\
\text { imply the design and } \\
\text { selection of appropri- } \\
\text { ate maintenance policy }\end{array}$ \\
\hline $\begin{array}{l}\text { Maintenance planning } \\
\text { and scheduling }\end{array}$ & $\begin{array}{l}\text { The first phase to } \\
\text { create the maintenance } \\
\text { plan which is the } \\
\text { structured set of tasks } \\
\text { includes the activities, } \\
\text { procedures and re- } \\
\text { sources }\end{array}$ & $\begin{array}{l}\text { Maintenance planning } \\
\text { is aligned with the } \\
\text { objectives before } \\
\text { formulating the strate- } \\
\text { gy based on the speci- } \\
\text { fied standard. }\end{array}$ & $\begin{array}{l}\text { Using RCM for de- } \\
\text { signing the strategies } \\
\text { and maintenance plans }\end{array}$ & $\begin{array}{l}\text { Strategic and opera- } \\
\text { tional planning is } \\
\text { establishing the } \\
\text { maintenance objective } \\
\text { is to determine in the } \\
\text { earlier phase. }\end{array}$ & $\begin{array}{l}\text { Maintenance concepts } \\
\text { are determined by the } \\
\text { strategic level before } \\
\text { the tactical level trans- } \\
\text { formed it into the } \\
\text { maintenance policies. }\end{array}$ \\
\hline $\begin{array}{l}\text { Organizational } \\
\text { management }\end{array}$ & & $\begin{array}{l}\text { The responsibility and } \\
\text { communication of the } \\
\text { organization are under } \\
\text { the organization stage } \\
\text { after identification of } \\
\text { the maintenance activ- } \\
\text { ities. }\end{array}$ & $\begin{array}{l}\text { Three level: strategic, } \\
\text { tactical and operation- } \\
\text { al has different re- } \\
\text { sponsibilities and } \\
\text { actions in determining } \\
\text { the strategy, resource } \\
\text { allocation and imple- } \\
\text { mentation. }\end{array}$ & $\begin{array}{l}\text { The organizational } \\
\text { management describes } \\
\text { in the leading stage to } \\
\text { explain the structure } \\
\text { of the maintenance } \\
\text { organization regarding } \\
\text { the leadership, com- } \\
\text { munication, motivat- } \\
\text { ing and development. }\end{array}$ & $\begin{array}{l}\text { Considering all organ- } \\
\text { izational levels, the } \\
\text { importance of mainte- } \\
\text { nance objective and } \\
\text { several indicators } \\
\text { (strategic, tactical and } \\
\text { operational level). } \\
\text { Each level has their } \\
\text { strategic maintenance } \\
\text { responsibility and } \\
\text { scope of work. }\end{array}$ \\
\hline Resources allocation & $\begin{array}{l}\text { Resource allocation as } \\
\text { an input to the mainte- } \\
\text { nance process during } \\
\text { the decision making to } \\
\text { achieve maintenance } \\
\text { objectives. }\end{array}$ & $\begin{array}{l}\text { The resources alloca- } \\
\text { tion is included in the } \\
\text { requirements needed } \\
\text { during organizing } \\
\text { stage. }\end{array}$ & $\begin{array}{l}\text { Stage } 5 \text { describes the } \\
\text { allocation of resources } \\
\text { being made during the } \\
\text { scheduling of mainte- } \\
\text { nance activities to } \\
\text { minimize the impact } \\
\text { on production. }\end{array}$ & $\begin{array}{l}\text { The human resources } \\
\text { and the use of material } \\
\text { within the specific } \\
\text { financial support. }\end{array}$ & $\begin{array}{l}\text { Only describe the } \\
\text { roles of three maturity } \\
\text { level (strategic, tacti- } \\
\text { cal and operational. }\end{array}$ \\
\hline $\begin{array}{l}\text { Operation } \\
\text { management }\end{array}$ & $\begin{array}{l}\text { The term "Do" de- } \\
\text { scribe the maintenance } \\
\text { execution and func- } \\
\text { tional testing of an } \\
\text { item which conducted } \\
\text { periodically to estab- } \\
\text { lish and verify the } \\
\text { current condition of } \\
\text { the subject. }\end{array}$ & $\begin{array}{l}\text { The execution of } \\
\text { maintenance task is in } \\
\text { the implementation } \\
\text { stage starting form } \\
\text { buildings' inspection } \\
\text { until the job is carried } \\
\text { out }\end{array}$ & $\begin{array}{l}\text { Maintenance execu- } \\
\text { tion is conducted once } \\
\text { scheduling the strategy } \\
\text { and allocation of re- } \\
\text { sources being made. }\end{array}$ & $\begin{array}{l}\text { The implementation } \\
\text { stage defines the } \\
\text { maintenance operation } \\
\text { supported by human, } \\
\text { process, facility and } \\
\text { technology to execute } \\
\text { the maintenance. }\end{array}$ & $\begin{array}{l}\text { Consists of few com- } \\
\text { ponents: describe the } \\
\text { activities/elements at } \\
\text { each dimension and } \\
\text { performed at each } \\
\text { maturity level }\end{array}$ \\
\hline Financial control & & & $\begin{array}{l}\text { Cost is one of the } \\
\text { KPIs; therefore, the } \\
\text { financial is considered } \\
\text { from early phase to- } \\
\text { wards the end, and } \\
\text { LCC analysis is used } \\
\text { to determine the value } \\
\text { associated with the } \\
\text { maintenance activities. }\end{array}$ & $\begin{array}{l}\text { The financial aspect is } \\
\text { considered under } \\
\text { organizing stage de- } \\
\text { pending on the process } \\
\text { of maintenance to be } \\
\text { implemented. }\end{array}$ & $\begin{array}{l}\text { Budgeting process } \\
\text { under strategic level. } \\
\text { Maintenance cost only } \\
\text { describes as one of the } \\
\text { performance indica- } \\
\text { tors. }\end{array}$ \\
\hline $\begin{array}{l}\text { Information } \\
\text { management }\end{array}$ & $\begin{array}{l}\text { Term "Feedback" of } \\
\text { information used to } \\
\text { represents the loop } \\
\text { from maintenance } \\
\text { execution to validate } \\
\text { the maintenance doc- } \\
\text { umentation (manuals) }\end{array}$ & $\begin{array}{l}\text { The standards and } \\
\text { procedure indicates } \\
\text { the info available for } \\
\text { maintenance activities } \\
\text { and data is used for } \\
\text { monitoring and feed- } \\
\text { back of the mainte- } \\
\text { nance activities. }\end{array}$ & $\begin{array}{l}\text { The integration of } \\
\text { tools and enabling the } \\
\text { computer system for } \\
\text { maintenance process- } \\
\text { es. }\end{array}$ & $\begin{array}{l}\text { The technology used } \\
\text { in organizing and } \\
\text { implementing stage } \\
\text { describes the usage of } \\
\text { CMMS for data in- } \\
\text { formation. }\end{array}$ & $\begin{array}{l}\text { Analytical Network } \\
\text { Process (ANP) gener- } \\
\text { ates the information } \\
\text { on the maintenance } \\
\text { objective and organi- } \\
\text { zational levels. }\end{array}$ \\
\hline
\end{tabular}


Table 3: The identification of elements of maintenance management models and frameworks

\begin{tabular}{|c|c|c|c|c|c|}
\hline Parameters & $\begin{array}{l}\text { Söderholm et al., } \\
(2007)\end{array}$ & Idrus et al., (2009) & Barberá et al., (2012) & Harun et al., (2013) & $\begin{array}{l}\text { Chemweno et al., } \\
\text { (2015) }\end{array}$ \\
\hline $\begin{array}{l}\text { Performance } \\
\text { assessment and } \\
\text { control }\end{array}$ & $\begin{array}{l}\text { Each stage describes } \\
\text { the "feedback" to } \\
\text { monitor the perfor- } \\
\text { mance of the mainte- } \\
\text { nance programs } \\
\text { through the Improve- } \\
\text { ment Cycle. }\end{array}$ & $\begin{array}{l}\text { In the controlling } \\
\text { stage, the monitoring } \\
\text { of performance is } \\
\text { made to check if the } \\
\text { objective of mainte- } \\
\text { nance is achieved. }\end{array}$ & $\begin{array}{l}\text { Through feedback, the } \\
\text { model describes the } \\
\text { evaluation and moni- } \\
\text { toring of the mainte- } \\
\text { nance work for con- } \\
\text { tinual improvement. }\end{array}$ & $\begin{array}{l}\text { The measurement of } \\
\text { performance is based } \\
\text { on the feedback and } \\
\text { compliance of the } \\
\text { maintenance pro- } \\
\text { grams. }\end{array}$ & $\begin{array}{l}\text { Assessment approach } \\
\text { is made by comparing } \\
\text { the maintenance per- } \\
\text { formance with the } \\
\text { benchmark sets in the } \\
\text { early stage. }\end{array}$ \\
\hline
\end{tabular}

